\title{
Os Ciganos do Catumbi \\ De "andadores do Rei" e comerciantes de escravos a oficiais de justiça na cidade do Rio de Janeiro ${ }^{l}$
}

\author{
Marco Antonio da Silva Mello*; Felipe Berocan Veiga; \\ Patrícia Brandão Couto; Mirian Alves de Souza **
}

\begin{abstract}
Resumo: Este artigo discute a participação dos ciganos calon no comércio de escravos africanos e no poder judiciário carioca desde a corte de D. João VI, analisando as práticas comerciais e a formação de redes de organizações e relações informais. A presença desse grupo no mais importante mercado de cativos e numa instituição pública cuja lógica se baseia nos laços impessoais e contratuais, constitutivos vida urbana, oferece-nos uma interessante oportunidade de reflexão sobre as formas de negociação a partir das quais os ciganos conseguiram, na esfera do trabalho, uma inserção de destaque na cidade do Rio de Janeiro. Suas estratégias revelam a alta competência sociológica do grupo ao ocupar um nicho de mercado, valendo-se da habilidade para comercializar mercadorias freqüentemente preteridas pela grande empresa traficante (os chamados "escravos de segunda-mão") e para incluir nas "custas", as despesas de um litígio, gorjetas estabelecidas mediante uma arguciosa negociação com as partes envolvidas num processo judicial.
\end{abstract}

Palavras-Chaves: Ciganos calon; Comércio de escravos; Poder judiciário; Rio de Janeiro.

\section{Um ofício e um lugar na Corte}

A relação entre os ciganos da "Cidade Nova" - área de expansão do Rio de Janeiro no século XIX, hoje zona central - e o poder judiciário carioca revela-se como uma forma muito oportuna para apreendermos como um grupo pária conseguiu fugir do estatuto subalterno em que se encontrava nos mais diversos países e, sem dissociar-se comple- tamente do seu grupo de origem e do conjunto de estereótipos que lhe é tradicionalmente atribuído, conquistar um estatuto operatório que lhe garantiu o estabelecimento de determinadas práticas sócioeconômicas.

Muitas vezes, a identidade do grupo étnico estudado impõe uma definição de situações sociais que não lhes permite estabelecer uma ampla interação com os membros da sociedade majoritária e que

\footnotetext{
${ }^{1}$ Uma primeira versão deste artigo foi publicada em francês na revista Études Tsiganes (n. 21, Les institutions: un espace de rencontres. Paris: FNA-SAT, 2005, pp. 12-33). Os ciganos da "Cidade Nova" e o judiciário carioca tornaram-se objeto de nossa atenção porque, em uma conferência, Marco Antonio da Silva Mello apresentou, contrastivamente, o resultado de suas pesquisas etnográficas no Catumbi, um bairro popular da área central de negócios da cidade do Rio de Janeiro, e em Belleville, o emblemático quartier do XXème. arrondissement de Paris. Ao evocar a curiosa relação entre um Pariavolk, os ciganos calon, e uma instituição tradicional diretamente ligada ao Estado, o poder judiciário, Marc Bordigoni o convidou para participar do colóquio em Aix-en-Provence, Tziganes et Méditerranée: les institutions comme espaces de rencontres, organizado pelo Institut d'Éthnologie Méditerranéenne et Comparative (IDEMEC-CNRS), em maio de 2002, estimulando o desenvolvimento desta pesquisa. Agradecemos aos colegas Marc Bordigoni, Flávio Gomes, Samuel Araújo e Antonio Guerreiro, sem os quais não teria sido possível realizar este trabalho. Aos oficiais de justiça José Mello da Rocha Neto, Ivan Castro Almeida, Joaquim Ribeiro, Alípio Mendes e Galba Loureiro; ao tabelião Nadilvar Caetano Gomes; aos juízes José Lisboa Gama Malcher, João Antonio da Silva, Paula Galhardo e João Batista Damasceno; ao promotor de justiça Heitor Costa Jr.; e aos advogados Vivalde de Araújo Brandão Couto Filho e Paulo Rogério de Araújo Brandão Couto, pela disponibilidade e pelas gentis e enriquecedoras informaçōes à nossa pesquisa no campo jurídico; ao músico e ativista cigano Mio Vacite pelo diálogo profícuo; ao Padre Mário Prigol, a Toninho e a Ítalo Brescia (in memoriam), nossos hóspedes e interlocutores durante os anos de pesquisa etnográfica no bairro do Catumbi. Finalmente, agradecemos a Alexandra Castro pelo generoso convite para a publicação em Portugal e a Paulo Thiago de Mello pela tradução em inglês do resumo.

* Professor Doutor do Programa de Pós-Graduação em Antropologia (PPGA/ICHF-UFF); Professor do Departamento de Antropologia Cultural da UFRJ (DAC/IFCS-UFRJ); Coordenador do Laboratório de Etnografia Metropolitana (LeMetro/IFCS-UFRJ). LeMetro - Largo de São Francisco de Paulo, n. 01 , sala 417 - Centro. Rio de Janeiro - RJ, Brasil. CEP 20.051-070. Tel. (55-21) 2221-7539. Portal na internet: http://www.ifcs.ufrj. br/ lemetro

E-mail: mello@ifes.ufrj.br

*** Pesquisadores do Laboratório de Etnografia Metropolitana (LeMetro/IFCS-UFRJ) e do Programa de Pós-Graduação em Antropologia (PPGA/ICHF-

-UFF).E-mails: fbveiga@yahoo.com; patcouto@centroin.com.br; mirian_uff@yahoo.com.br
} 
acaba os impedindo de assumir estatutos normais, ou melhor, comuns à população de uma maneira geral. No Brasil, no entanto, observamos que a identidade como membro de uma minoria forneceu aos ciganos que habitavam os arredores da Cidade Nova, mais especificamente àqueles do Catumbi, um tradicional bairro da cidade do Rio de Janeiro, uma considerável base para a ação ${ }^{2}$.

Tal ação se desenhou, primeiramente, no comércio interprovincial, onde eram os ciganos comerciantes de escravos e de cavalos. A efetiva participação desse grupo no sistema escravista brasileiro foi devidamente registrada por viajantes e naturalistas e, mais recentemente, por historiadores cuja análise dos registros das operações mercantis ocorridas na cidade do Rio de Janeiro evidencia um lugar de inserção privilegiada em nossa sociedade.

Em um segundo momento, inicialmente como membros da indispensável burocracia do Desembargo do Paço, à época ápice do sistema judicial, ocupando, sobretudo, o cargo de meirinhos, hoje oficiais de justiça ${ }^{3}$. Nessa nova ocupação, ainda na condição de perspicazes negociadores, os ciganos participam de uma economia relacionada aos processos judiciais, isto é, através das custas, eles obtêm um complemento salarial que, embora não instituído por dispositivos legais, mas tradicionalmente tolerado pelo poder judiciário, é estabelecido mediante negociação com as partes envolvidas no litígio. $\mathrm{O}$ estudo da instauração dessa verdadeira trama comercial revelará ainda a teia complexa de outros relacionamentos sociais e econômicos que, como poderemos verificar, constitui o judiciário carioca.

\section{Do degredo ao epicentro da vida social}

Em artigo publicado no Journal of Social History, em 1992, Bill Donovan faz uma estimulante apreciação a respeito das possibilidades e perspectivas de uma história social dos ciganos. Para tanto, considera oportuno, como ponto de partida, a análise do significado particular do desvio social, associado a esse grupo étnico ao longo da história, e as mudanças na sua percepção. Perse- guidos desde os primórdios da modernidade, tanto por sua identidade étnica e cultural, quanto por sua mobilidade e caráter constantemente postos sob suspeita, os ciganos encontraram uma severa repressão em Portugal, diante da legislação formulada especificamente para coibir o grupo, caso que é analisado pelo autor.

Sucessivas leis como, por exemplo, a de D. Filipe, em 1592, proibiam a entrada dos ciganos no Reino, bem como o uso de sua língua e vestuário, marcas evidentes de sua identidade. Limitavam tanto seu nomadismo, entendido como sinônimo de vagabundagem, quanto o estabelecimento de grupos sedentários, reunidos em um território comum:

"Ey por bem e mando, que todos os Ciganos (...) se saião dos ditos Reinos, onde mais não entrarão, sob pena de morte natural. E porém querendo ficar, o poderão fazer, com tanto que não andem em trajos de Ciganos nestes Reinos, nem falem sua lingoa (...) e se avisinhem nos Lugares, sem andarem vagabundos. (...) não os consentindo viver em bairros apartados de per si, mas que estem misturados entre os outros visinhos. (...) e as mulheres dos ciganos (...) não o fazendo assim, serão publicamente açoutadas com baraço e pregão, e degredadas para sempre para o Brazil" (Collecção da Legislação Antiga e Moderna do Reino de Portugal, 1819: 205-206).

Já no século XVIII, a ordenação do banimento de todos os ciganos para as colônias portuguesas de além-mar caracterizou o reinado de D. João V. Demonstrações públicas desses atos contribuíam para atualizar um novo e forte aparato da justiça real, que culminou com o dramático embarque de uma comunidade inteira, noticiada na Gazeta de Lisboa de 10 de Março de 1718. Donovan observa que "a cena dos ciganos soltando as amarras assinalava para os espectadores reunidos os esforços da Coroa no controle social" (Donovan, 1998:39).

O degredo sistemático para as colônias, entretanto, teve como conseqüência um novo lugar social reservado aos ciganos na hierarquia da sociedade

${ }^{2}$ O cotidiano do bairro do Catumbi e de seus moradores é o tema do livro Quando a Rua Vira Casa, de Marco Antonio da Silva Mello, Arno Vogel, Carlos Nelson Ferreira dos Santos et al. O trabalho etnográfico apresenta a pluralidade étnica do bairro e as ruas do Chichorro e Emília Guimarães como endereços dos ciganos calon, tendo como principal devoção o culto a Nossa Senhora das Graças, celebrada no dia 27 de novembro (Mello, Vogel et al., 1981:46-47).

${ }^{3}$ Outras considerações da pesquisa sobre os "meirinhos aristocráticos" foram publicadas no Dossiê Ciganos no Brasil: Quem São? De Onde Vieram?, da Revista de História da Biblioteca Nacional (Mello \& Souza, 2006:29-32). 
colonial brasileira, onde eram os escravos negros africanos que ocupavam o seu nível mais baixo. No Brasil, os ciganos gradualmente foram se incorporando à sociedade local entre os brancos da classe baixa, diluindo fronteiras étnicas e culturais. Não tiveram dificuldades em encontrar ocupação, participando de atividades tanto da vida urbana quanto do comércio interprovincial, sobretudo aquelas ligadas ao tráfico de escravos e ao comércio de animais de montaria.

Sua inserção peculiar no sistema escravista, entretanto, não se deu por acaso. Representava não somente sua inserção na sociedade mais ampla, como também sua reconhecida competência no "controle de um espectro inteiro de interação étnica" (Donovan, 1992:42), atribuindo aos ciganos uma função e uma posição no sistema de relações sociais muito diferentes das que vigoravam àquela época na metrópole portuguesa.

No século XIX, alguns viajantes da missão francesa ao Brasil deram notícias da presença marcante dos ciganos como intermediários do comércio escravo, sobretudo dos chamados "escravos de segunda mão", na antiga Rua do Valongo (Saint-Hilaire, 1976:102). Jean-Baptiste Debret, pintor francês de sensibilidade etnográfica no registro da vida social brasileira, retratou-os em duas pranchas em seu livro Viagem Pitoresca e Histórica ao Brasil, ambas relacionadas com tal posição na estrutura colonial. Ao descrever o amplo pátio interno de uma residência de ciganos, Debret registra: "a casta dos ciganos caracteriza-se tanto pela capacidade como pela velhacaria que põe no seu comércio exclusivo de negros novos e de escravos civilizados, conseguidos por intermédio de agentes que os seduzem e raptam" (Debret, 1975:191).

\section{Figura 1}

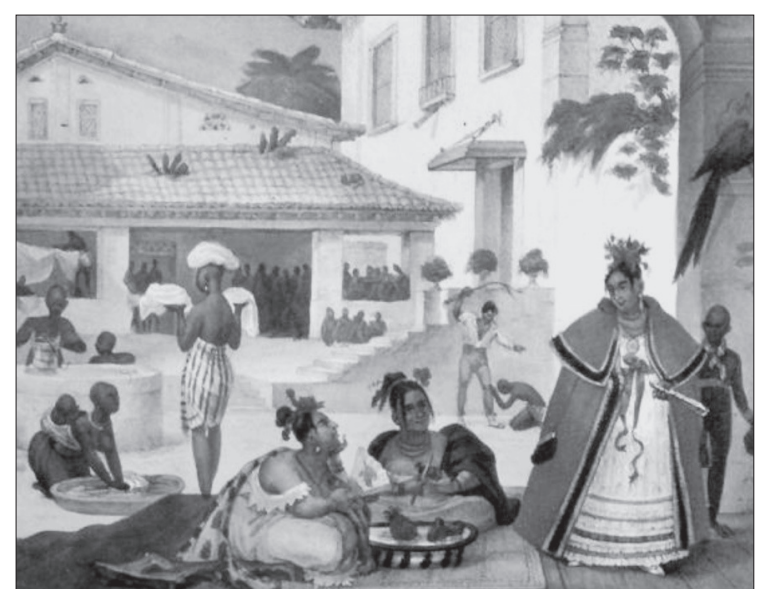

Interior de uma Residência de Ciganos, gravura de Jean-Baptiste Debret (1823)
A sedução era uma modalidade de fuga, amplamente estimulada pelos ciganos, na qual os escravos, em conspiração com estes bem situados mediadores do tráfico, mudavam de senhor; o que por vezes poderia também ocorrer a contragosto como, por exemplo, no caso dos raptos e roubos de escravos (Soares \& Gomes, 2001:14). Segundo os colegas historiadores Carlos Eugênio Líbano Soares e Flávio Gomes, os ofícios policiais e os anúncios de jornais, no início do século XIX, no Rio de Janeiro, são fontes preciosas da prática de sedução, que implicava uma complexa rede. Assim nos informam os autores:

"Consta que cada cigano, ladrão de escravos, era ajudado por um cativo, crioulo ou africano, que se aproximava furtivamente da 'vítima', e, através do 'diálogo', a convencia das possibilidades do esquema de fuga. (...) Seu campo de caça predileto estava no Largo da Carioca, onde se concentrava a massa escrava. Ali eles eram ajudados pelos próprios escravos, que eram chamados línguas (truchement), por falarem os diferentes dialetos dos cativos, tal como o africano Mahitica em seu ofício de Bomba. Estes 'mestres da astúcia', nas palavras do Intendente da Corte, prometiam para os escravos camisas finas, mulheres e "grandes fortunas" (Soares \& Gomes, 2001:17).

Figura 2

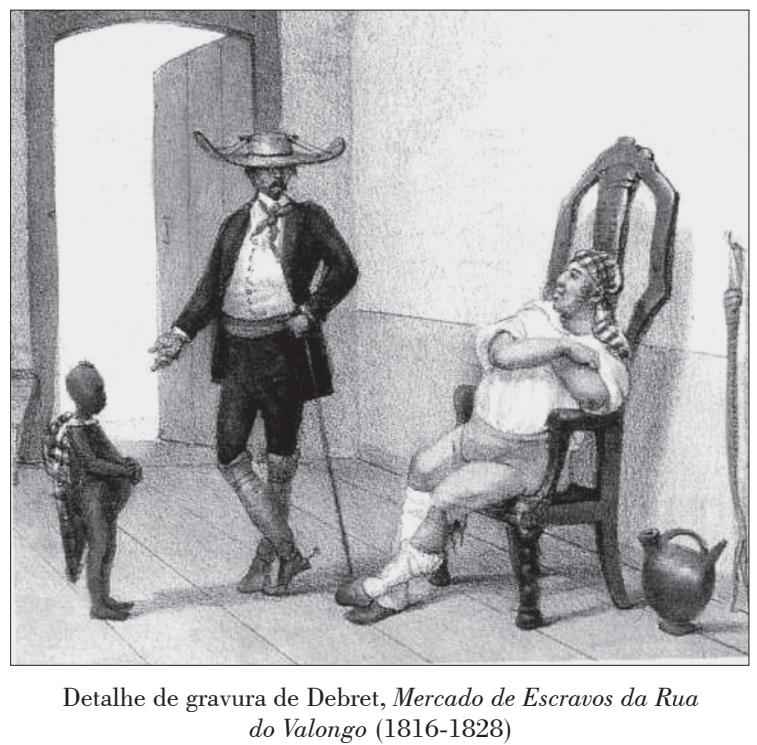

Descendente de uma importante família de botânicos do Jardin des Plantes de Paris, Auguste de Saint-Hilaire foi o viajante que mais atenção deu à malha dos caminhos interprovinciais, seu 
comércio e movimento constantes. Em viagem a São Paulo, em 1819, o naturalista encontrou um grande acampamento de ciganos dedicados aos negócios e trocas de burros e cavalos:

"Pareceu-me um povo muito unido, e fui tratado por eles com grande benevolência. Não os ouvi jamais usar outra língua senão a portuguesa. Vestiam-se como brasileiros, mas usavam barbas e cabelos longos. Perguntei-lhes por que deixavam crescer a barba, em desacordo com os usos da região, mas a esse respeito só encontrei respostas evasivas. Todos pareciam em boa situação, possuíam escravos e um grande número de cavalos e de bestas de carga. (...)

Os ciganos de Urussanga passaram o dia inteiro tentando fazer trocas com os donos das tropas que compartilhavam comigo o rancho. Gracejando, comentei com um deles sobre a falta de probidade de que era acusado o seu povo. 'Eu trabaceio o mais que posso', respondeu-me ele com seriedade, 'mas todos os com quem negocio fazem o mesmo. A única diferença é que eles põem a boca no mundo quando se vêem apanhados, ao passo que nós, quando isso acontece, não dizemos nada a ninguém?." (Saint-Hilaire, 1976:102-103).

No mesmo local, um homem aparentando ser o mais velho de seu grupo, depois de haver observado longamente o naturalista em seu trabalho, perguntou a Saint-Hilaire se ele era médico, ao que respondeu negativamente. Ouviu então do cigano o seguinte comentário como réplica:

"O senhor não quer admitir isso; mas se não fosse médico não andaria colhendo uma variedade tão grande de plantas." (Saint-Hilaire, 1976:103).

Diante de argumentos irrefutáveis, Saint-Hilaire termina por se resignar e, usando ele mesmo de astúcia, prescreveu ao velho homem uma vida mais calma e sem excessos. Satisfeito, o velho cigano se afastou antes de retornar, momentos depois, para oferecer um pedaço de carne fresca ao naturalista, coisa que havia muito tempo não consumia, desde sua partida do Rio de Janeiro.

No início do século XIX, os dois maiores grupos de ciganos sedentários do Brasil viviam localizados estrategicamente nas cidades de Salvador, Bahia, e no Rio de Janeiro. Nessas duas cidades portuárias, estabeleceram-se, sobretudo, ao redor do mercado de escravos, passando logo a ocupar áreas importantes do centro. A presença dos ciganos na morfologia social do Rio de Janeiro está, pois, inscrita na sua topografia e na lógica dos lugares do sitio urbano.

$\mathrm{Na}$ capital da colônia, fixaram-se primeiramente no Campo dos Ciganos (atual Praça Tiradentes), na Rua dos Ciganos (atual Rua da Constituição) e no Campo de Santana, lugares cuja ambiência urbana é descrita por inúmeros cronistas da época, dentre eles Luiz Gonçalves dos Santos, o Padre Perereca, em suas Memórias para Servir à História do Reino do Brasil (Santos, 1981:109).

Em 1808, com a cidade transmudada em Corte, desabrochando em pompas reais, a velha imagem do cigano como pária em Portugal já era completamente diferente. No Brasil, ao contrário, passaram a integrar a vida cotidiana da cidade, ocupando uma posição estrategicamente bem definida na sociedade. Podemos encontrar na literatura da época uma deliciosa restituição desse período, evocada no próprio artigo de Bill Donovan:

"A corte encontrou uma comunidade cigana florescente quando chegou ao Rio de Janeiro. Além do tráfico de escravos, os ciganos tiveram ocupações como artesãos e até alguns poucos postos oficiais. Ainda que muitos eram seguramente das classes baixas, algumas famílias tornaram-se ricas. $\mathrm{O}$ cigano José Rabelo, por exemplo, foi considerado um dos cidadãos mais ricos do Rio de Janeiro. Para os recém-chegados europeus, os ciganos do Rio adicionavam um ar exótico à ambiência tropical. Em um ato impensável em Portugal, dançarinos foram convidados para as festividades de núpcias que marcaram o casamento da filha mais velha de D. João VI" (Donovan, 1992:46-47).

No aniversário do Príncipe Regente D. João, em 12 de outubro de 1810, Padre Perereca descreve as festividades no Campo de Santana para "Sua Majestade do Reino Unido de Portugal, Brasil e Algarve": 
“(...) logo entrou na praça a célebre dança dos ciganos, que se compunha de seis homens, e outras tantas mulheres vestidos todos com muita riqueza; pois tudo quanto apresentaram era veludo, e ouro: precedia-os uma banda instrumental; e sobre um estrado fronteiro às reais pessoas executaram com muito garbo, e perfeição, várias danças espanholas, que mereceram universal aceitação. Estas foram as únicas danças, que esta primeira tarde tiveram a honra de aparecer diante de Suas Majestades, as Altezas Reais (...)" (Santos, 1981:211).

A respeito de outra ocasião e festividade, a presença de alegres grupos de jovens ciganos ocupa, mais uma vez, o centro da atenção geral, agora registrada pelo Barão de Eschwege, que comenta admirado o acontecimento:

"Os ciganos foram convidados para as festas que se celebraram na capital do Brasil por ocasião do casamento da filha mais velha do Rei D. João VI com um infante da Espanha. Os moços dessa nação entraram no circo montando belos cavalos ricamente ajaezados e levando na garupa as suas noivas. Os casais saltaram ao chão com incrível agilidade e executaram, em conjunto, as mais lindas danças que já vi até hoje. Todos os olhos se achavam voltados para os jovens ciganos, e se tinha a impressão de que as outras danças tinham por único objetivo fazer ressaltar a beleza das suas" (Eschwege, Brasilien die neue Welt, v. II apud Saint-Hilaire, 1976:102-103).

As comemorações, em 1815, da elevação do Brasil à categoria de Reino Unido levaram ao Campo dos Ciganos não somente D. João VI e toda a Corte, mas até mesmo as delegações estrangeiras, para uma tarde e noite de dança e divertimento festivo ${ }^{4}$. Havia rumores de que o rei estava fascinado por uma cigana em particular. Doce ironia, uma vez que foi o ódio devotado aos ciganos por seu avô D. João V que os trouxe em cativeiro, banidos com suas famílias para o Brasil. Os anos seguintes veriam o Campo dos Ciganos transformarem-se na vizinhança boêmia do Rio por excelência, conhecida por sua alegre vida noturna e por abrigar o imponente Real Teatro São João, atraindo artistas brasileiros e estrangeiros.

Manuel Antonio de Almeida, autor do século XIX, inicia seu livro Memórias de um Sargento de Milícias, considerado o primeiro romance urbano brasileiro, retratando saborosamente a ambiência de uma esquina particular do centro da cidade. Nela surge um peculiar e influente personagem público, típico da vida urbana nos tempos de D. João VI:

"Era no tempo do rei.

Uma das quatro esquinas que formam as ruas do Ouvidor e da Quitanda, cortando-se mutuamente, chamava-se nesse tempo - $O$ canto dos meirinhos; e bem lhe assentava o nome, porque era aí o lugar de encontro favorito de todos os indivíduos dessa classe (que gozava então de não pequena consideração). Os meirinhos de hoje não são mais do que a sombra caricata dos meirinhos do tempo do rei; esses eram gente temível e temida, respeitável e respeitada; formavam um dos extremos da formidável cadeia judiciária que envolvia todo o Rio de Janeiro no tempo em que a demanda era entre nós um elemento de vida: o extremo oposto eram os desembargadores. Ora, os extremos se tocam, e estes, tocando-se, fechavam o círculo dentro do qual se passavam os terríveis combates das citações, provarás, razões principais e finais, e todos esses trejeitos judiciais que se chamava o processo.

Daí sua influência moral.

Mas tinham ainda outra influência, que é justamente a que falta aos de hoje: era a influência que derivava de suas condições físicas. Os meirinhos de hoje são homens como quaisquer outros; nada têm de imponentes, nem no seu semblante nem no seu trajar, confundem-se com qualquer procurador, escrevente de cartório ou contínuo de repartição. Os meirinhos desse belo tempo não, não se confundiam com ninguém; eram originais, eram tipos, nos seus semblantes transluzia um certo ar de majestade forense,

${ }^{4}$ Os ciganos do Catumbi até recentemente promoviam festas familiares chamadas de bródios, considerados pelos etnomusicólogos Samuel Araújo e Antonio Guerreiro como o lugar de expressão do samba cigano, uma das matrizes menos conhecidas da dança e da música popular carioca, mas referidas por Pixinguinha e João da Baiana em seus depoimentos no Museu da Imagem e do Som (Araújo \& Guerreiro, 1999). 
seus olhares calculados e sagazes significavam chicana. Trajavam sisuda casaca preta, calção e meias da mesma cor, sapato afivelado, ao lado esquerdo aristocrático espadim, e na ilharga direita penduravam um círculo branco, cuja significação ignoramos, e coroavam tudo isto por um grave chapéu armado. Colocado sob a importância vantajosa destas condições, o meirinho usava e abusava de sua posição. Era terrível quando, ao voltar uma esquina ou ao sair de manhã de sua casa, o cidadão esbarrava com uma daquelas solenes figuras que, desdobrando junto dele uma folha de papel, começava a lê-la em tom confidencial! Por mais que se fizesse não havia remédio em tais circunstâncias senão deixar escapar dos lábios o terrível - Dou-me por citado. - Ninguém sabe que significação fatalíssima e cruel tinham estas poucas palavras! Eram uma sentença de peregrinação eterna que se pronunciava contra si mesmo; queriam dizer que se começava uma longa e afadigosa viagem, cujo termo bem distante era a caixa da Relação, e durante a qual se tinha de pagar importe de passagem em um sem-número de pontos; o advogado, o procurador, o inquiridor, o escrivão, o juiz, inexoráveis Carontes, estavam à porta de mão estendida, e ninguém passava sem que lhes tivesse deixado, não um óbolo, porém todo o conteúdo de suas algibeiras, e até a última parcela de sua paciência.

Mas voltemos à esquina. Quem passasse por aí em qualquer dia útil dessa abençoada época veria sentado em assentos baixos, então usados, de couro, e que se denominavam - cadeiras de campanha - um grupo mais ou menos numeroso dessa nobre gente conversando pacificamente em tudo sobre que era lícito conversar: na vida dos fidalgos, nas notícias do Reino e nas astúcias policiais do Vidigal. Entre os termos que formavam essa equação meirinhal pregada na esquina havia uma grande constante, era o Leonardo-Pataca. Chamavam assim a uma rotunda e gordíssima personagem de cabelos brancos e carão avermelhado, que era o decano da corporação, o mais antigo dos meirinhos que viviam nesse tempo. A velhice tinha-o tornado moleirão e pachorrento; com sua vagareza atrasava o negócio das partes: não o procuravam; e por isso jamais saía da esquina; passava ali os dias sentado na sua cadeira, com as pernas estendidas e o queixo apoiado sobre uma grossa bengala, que depois dos cinqüenta era a sua infalível companhia. Do hábito que tinha de queixar-se a todo o instante de que só pagassem por sua citação a módica quantia de 320 réis, lhe viera o apelido que juntavam ao seu nome" (Almeida, 1978:5-6).

No Largo do Rocio (nome posteriormente dado ao Campo dos Ciganos), nos idos de 1850, essas insólitas figuras do urbano aparecem também, com sutileza de detalhes, na crônica que lhes dedicou Mello Moraes Filho, em seu livro Factos e Memórias:

"Destacando-se com singular originalidade, engastado naquela praça como um bazar do Oriente, o saguão do Teatro São Pedro, a qualquer hora do dia, povoava-se de um pessoal na realidade bizarro. Homens de cor trigueira ou esbranquiçada, de barba à inglesa, barrigudos ou completamente desbarrigados, trajando casaca azul ou cor de rapé com botões de latão, chapéu branco de castor, colete espantado e calça de ganga amarela, ali perambulavam, trocando palavras de gíria (chibe), saindo e entrando, de conformidade com as urgências do momento. Em grupos de três ou quatro, empunhando bengalas de cana da Índia, com os dedos enfiados em anéis, de grossos grilhões de ouro a tombar-lhes do pescoço prendendo o relógio, de argolinha à orelha alguns, e de pulseira de ouro com figas e verônicas, outros, eram os velhos ciganos da Cidade Nova, que se exibiam, os provectos oficiais de justiça, que se instalavam em galeria de baixo do terraço, à espera de citações e mandados de penhora" (Moraes filho, 1904:140-141).

É interessante notar que a literatura acima mencionada se coaduna com as evidências etnográficas com as quais nos deparamos no trabalho de campo. O cigano José Mello da Rocha Neto, oficial de justiça aposentado, ao ser abordado sobre como o seu bisavô teria ingressado no poder judiciário na condição de "porteiro de auditório", o que atu- 
almente equivale à posição de "leiloeiro", nos deu a seguinte resposta:

"Ah, isso eu não sei, mas ouvi comentários de que o cigano do Catumbi veio para o Brasil durante o período do bloqueio continental, na comitiva do D. João VI. Então, naquela época vieram cinco famílias: Os Duarte, os Catanheda, os Braz, os Vienas e uma outra que eu não me lembro o nome. Eles vieram nessa comitiva com a família imperial, e ficaram morando ali nas imediações de São Cristóvão; rua Bela, rua da Cancela, rua da Boa Vista... E começaram a freqüentar as dependências do judiciário para tratar dos documentos de transferência de compra e venda de escravos... Eles trabalhavam ali tratando daquela documentação, aí passaram a conhecer os serventuários e os juízes que naquela época tinham outros títulos" (José Mello da Rocha Neto, Setembro de 2003).

De acordo com este depoimento, os ciganos, particularmente os do Catumbi, de modo distinto daqueles que foram degredados, chegaram ao Brasil na companhia da Família Real, estabelecendo-se em uma área da cidade que, àquela época, abrigava famílias abastadas em seu nobre casario ${ }^{5}$. Tal inserção especial em terras brasileiras é assinalada pela memória do grupo em outros depoimentos, os quais compõem uma interessante narrativa fundacional, circunscrita às cinco famílias que se fixaram, inicialmente, nos lugares acima nomeados ${ }^{6}$. Essa narrativa é significativamente importante, pois lhes atribui um status de caráter afirmativo e atualiza constantemente para o próprio grupo o fato de que, na sociedade brasileira, conseguiram dissociar-se de uma identidade impresumível.

Outro fator relevante nos leva às dependências do judiciário, onde os ciganos, da condição de comerciantes de escravos, passam gradativamente à condição de meirinhos, hoje oficiais de justiça. Por conta da regulamentação das operações mercantis, os ciganos freqüentavam o judiciário para tratar dos documentos de transferência de compra e venda de escravos. Foi dessa forma que conseguiram se inserir nas malhas do judiciário, sobretudo, como oficiais de justiça.

$\mathrm{O}$ oficial de justiça, embora seja um empregado inferior do juízo ou da administração, a quem compete efetuar citações, intimações e outras diligências, figura, tal como podemos constatar nos romances e nas crônicas, como uma personalidade pública que goza de certo prestígio. A importância atribuída a ele sobrevive no espectro do judiciário, pois, como é recorrentemente assinalado, desempenhavam sua função pública com firmeza e autoridade. Para executar a ordem a eles confiada, praticavam um interessante rito: munidos de um longo bastão ${ }^{7}$, tal como um lictor romano, e prolatavam em alta voz a sentença, causando enorme constrangimento para o intimado.

"Eles pegavam o sujeito desprevenido no meio da rua, na porta de casa ou de algum estabelecimento comercial e faziam aquela cena: batiam a bengala no chão três vezes - pá... pá... pá... - todo mundo olhava e aí eles começavam: 'por decisão da vara tal, o senhor fulano está intimado a comparecer na corte...' Olha minha filha, era um vexame!" (Nadilvar Caetano Gomes, Novembro de 2001).

Embora o parecer de Buzaid sobre a carreira do oficial de justiça aponte esse rito como um antigo costume dos meirinhos, o tabelião aposentado Nadilvar Caetano Gomes ${ }^{8}$ acredita que esse era um modo de agir particularmente dos ciganos:

\footnotetext{
${ }^{5}$ Com base na literatura e nos cronistas, Arthur Ramos dedicou atenção a esse grupo étnico em sua Introdução à Antropologia Brasileira: as culturas européias e os contactos raciais e culturais. Destacou a presença dos ciganos no Rio de Janeiro "vindos numa comitiva real", exibindo suas artes eqüestres nas festas do consórcio de D. Pedro I e D. Leopoldina, e atuando como revendedores de escravos, na barganha comercial e como meirinhos no foro de justiça. Além das ruas do Centro, o autor registrou ainda, como "seus pontos preferidos" na cidade, bairros como Méier, Cachambi, Cidade Nova e os subúrbios da Central do Brasil (Ramos, 1947:266-274).

${ }^{6}$ Durante o trabalho de campo realizado no bairro do Catumbi, nos deparamos com um repertório comum de histórias acerca do grupo. A referência a essa origem, por exemplo, é recorrentemente assinalada por nossos interlocutores, sejam eles ciganos ou não-ciganos (gadjés).

${ }^{7}$ Em Burocracia e Sociedade no Brasil Colonial, de Stuart B. Schwartz, verificamos que o bastão era um simbólico apetrecho de identificação do corpo forense, daí o termo vara judicial. Por exemplo, o bastão vermelho simbolizava a autoridade do juiz ordinário e o bastão branco simbolizava o poder do juiz de fora (1979: 05).

${ }^{8}$ Nadilvar Caetano Gomes é tabelião aposentado, que ao longo de uma carreira de sessenta anos galgou o que se referiu como a "hierarquia natural de um cartório", que compreende as funções de: auxiliar de escritório, auxiliar de escrevente, escrevente autorizado, escrevente juramentado (atualmente denominado técnico do judiciário), escrivão substituto, escrivão e tabelião.
} 
"Quando você via aquele homem com uma bengala grande, podia saber que era oficial de justiça e cigano. Eles adoravam aquela empáfia!" (Nadilvar Caetano Gomes, Novembro de 2001).

Em seus ofícios de proximidade direta com o poder, os próprios ciganos do Catumbi também fazem referência ao antigo posto de Andadores do Rei, desempenhado pelo grupo no Desembargo do Paço - até porque já dispunham de tropas e arreios obrigatórios para o exercício do métier. Por conta dessa presença conspícua no mais importante edifício régio do Brasil, Oswaldo Macedo enviou um documento em agosto de 1986 - ou seja, quase dois séculos depois dos tempos joaninos - ao Diretor de Eventos do Paço Imperial, "em nome da Comunidade Cigana, (...) postulando o consentimento de marcar com uma placa de cobre (...) o nome do pátio interno referido, sancionado pelo povo: Adro dos Ciganos." A carta que, no entanto, jamais obteve resposta da direção do centro cultural em que se transformou o nobre edifício um ano antes, traz um breve e interessante relato do que seria a vida de seus antepassados calon naquele lugar:

"Como presença numerosa, de chofre, há que registrar os que aqui aportaram como parte ativa, posto que subalterna, da Corte de D. João VI.

Eles eram parte modesta, mas indispensável da burocracia do Paço. Eram cocheiros, palafreneiros, artesãos de cobre e de ferro, Andadores do Rei (oficiais de justiça), organizadores e participantes de festas populares - cavalhadas, touradas, serra-velha, jogo das argolinhas, etc.

Os ciganos tinham, principalmente os homens, uma atividade permanente, só interrompida nas horas das refeições que eles prolongavam em lazer, tipo sesta, no pátio interno do Paço Imperial, onde conviviam com a família, pessoas amigas e parentes, e, aos domingos, após o almoço, as ruidosas festas dos ciganos tinham lugar neste mesmo pátio interno, que era conhecido pelo povo como Adro dos Ciganos, embora não fosse este o nome oficial do logradouro, nem como tal reconhecido à época" (Oswaldo Macedo, ofício de 11 de Agosto de 1986).

\section{Um ofício hereditário}

Vimos até aqui os calon como ricos negociantes, mercadores de escravos, revendedores e agora como meirinhos. Mas, como chama atenção Morales de los Rios:

"Foi principalmente nesta última função que eles se destacaram. (...) A profissão de meirinho era transmitida de pai para filho, sendo sempre exercida com perfeita exação. (...) A partir do meado do século XIX, os ciganos acompanharam a expansão da cidade na direção ocidente, transferindo-se para a Cidade Nova" (Morale de los Rios Filho, 2000:69-70).

Stuart B. Schwartz, ao descrever o procedimento da Relação, antigo Tribunal de Justiça, faz referência ao fato de que os cargos de escrivão também podiam ser adquiridos e passados de uma geração à outra (1979:116). As relações interpessoais primárias baseadas em parentesco familiar, nesse sentido, estavam presentes na organização do judiciário, assim como em outras instituições brasileiras, e põem em relevo uma questão que é primordial, qual seja: como um sistema profundamente racionalizado, e cuja organização é extremamente burocrática, acomoda relações de parentesco, amizade e interesse.

A premissa básica da pesquisa sobre a burocracia no Brasil colonial, realizada por Schwartz e a qual compartilhamos, é de que, no caso brasileiro, o governo e a sociedade se estruturaram a partir de dois sistemas interligados de organização. De um lado, havia uma administração caracterizada por normas burocráticas e relações impessoais, que amarrava os indivíduos e os grupos às instituições políticas do governo formal. De outro, e paralelamente, existia uma teia de relações baseadas em parentesco e em objetivos comuns que, embora não menos formal, não contava com o reconhecimento formal (Schwartz,1979:XI). Observamos, diante do expressivo número de oficiais de justiça ciganos e, fundamentalmente, do comércio que envolvia as despesas feitas em processo judicial, o relacionamento possível entre esses dois sistemas de organização. Pois, como podemos indicar através da genealogia de algumas famílias ciganas, esse grupo conseguiu, durante gerações e de maneira bastante expressiva, ocupar funções públicas inscritas na estrutura do judiciário carioca. 


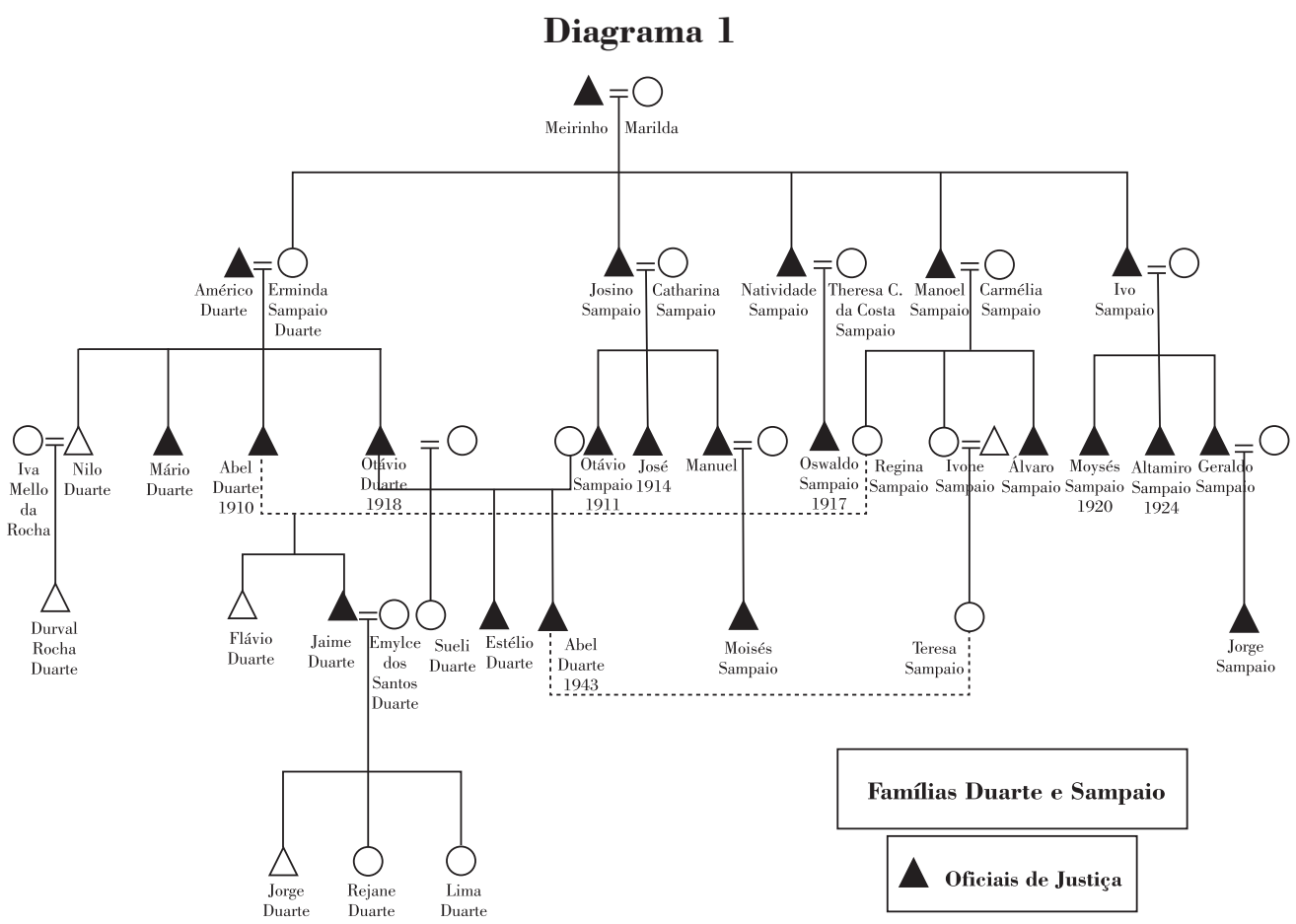

Genealogia das famílias Duarte e Sampaio, ressaltando os ciganos calon do Catumbi que atuaram no sistema judiciário do Rio de Janeiro

É relevante assinalar que, para alguns membros da hierarquia forense, um dos propósitos da pesquisa, qual seja, a relação entre os ciganos e a justiça, não parecia pertinente. Afinal, para cada domínio, deve-se corresponder um conjunto de identidades apropriadas, não sendo, para a "casta do judiciário", plausível a possível relação entre eles e membros de um grupo pária.

Em uma cerimoniosa confraternização da cúpula do judiciário carioca, em sua sede campestre, na localidade de Vargem Grande, observamos que a hipótese dessa relação causava a nossos interlocutores não somente perplexidade e estranhamento, mas um considerável desconforto. Para eles, tal relação implicava o contato entre sub-universos de significação cujos valores são, ao menos, em termos de representação, muito distintos. Nesse sentido, a impropriedade da conexão entre os ciganos e o judiciário era justificada a partir de uma tópica que entre "os ciganos não poderiam entrar num ambiente tão austero" e "cigano e justiça são duas coisas que não combinam".

Embora o contato entre os ciganos e a justiça nos parecesse indesejável e a consulta aos desembargadores Décio e Isaias, então responsáveis pela direção do Museu da Justiça, apontasse para a impropriedade da questão, o desembargador José Lisboa da Gama Malcher deu credibilidade ao tema, sendo categórico ao afirmar para seus colegas que, "de fato, houve um tempo na justiça em que boa parte dos oficiais eram ciganos, moradores do Catumbi" ". Diante disso, o assunto, que até então parecia um equívoco, transformou-se em matéria de interesse, adotando para os presentes um caráter exótico. Assim, outros desembargadores, como Mannes, resgataram de suas memórias a certificada presença dos ciganos na justiça do Rio de Janeiro.

Essa relativa invisibilidade, em parte, foi construída pelos próprios ciganos, pois, na esfera de interação no trabalho, operaram uma estratégia de distanciamento social, a qual foi certamente facilitada porque, diferentemente de outros serventuários, o oficial de justiça está somente subordinado ao juiz, ou seja, ele não precisa se relacionar tão intensamente com outros funcionários do juízo. Assim, os ciganos dissimularam sua identidade étnica, reconhecidamente desvantajosa:

"Queria ser inimigo de meu avô, era perguntar a ele se ele era cigano. Ele não gostava de jeito nenhum porque (...) não tem

${ }^{9}$ Segundo o cigano calon José Mello da Rocha Neto, oficial de justiça aposentado, na década de 1950, à época do seu ingresso no judiciário, o número total de oficiais era de 295 , dos quais cerca de 30 eram ciganos e moravam no Catumbi. 
nada qualificativo referente a cigano. Nada de bom é associado a cigano. Isto cria uma certa reserva" (José Mello da Rocha Neto, Setembro de 2003).

A reserva de que nos fala José Mello da Rocha Neto era uma forma de tentar regular a conduta dos outros, e principalmente a maneira como são tratados (Goffman, 1975:13). Isto é, embora em uma instituição majoritária como o judiciário, as afiliações étnicas não fossem formalmente reconhecidas ${ }^{10}$, a identidade étnica é um elemento importante no quadro que orienta as relações sociais. A etnicidade se emprega, dessa forma, como um conceito de organização social. Como sugere Barth, ela permite a interpretação das fronteiras e das relações dos grupos sociais em termos do repertório seletivo de contrastes culturais que são empregados emblematicamente para organizar identidades e interações (Barth,1984). Por isso, os ciganos, diante da possibilidade de sua identidade ser colocada em relevo, desenvolveram uma forma particular de gestão das impressões. Em outras palavras, na medida em que sua identidade étnica representava um estigma social, havia uma preocupação constante dos oficiais de justiça ciganos em manipular sua identidade no decorrer das interações. Assim, através de manobras dilatórias, os calon construíram um relativo isolamento.

Não obstante, alguns oficiais de justiça ciganos, tais como José Mello da Rocha Neto e o já falecido Paulo Barroso da Costa Verani, assinalaram a importância de se assumir a identidade cigana como uma iniciativa fundamental para a transformação da imagem negativa tradicionalmente associada a seu povo ${ }^{11}$.

As famílias Verani, Duarte, Sampaio, Salgado e Rocha, constantemente indicadas por nossos interlocutores, conseguiram ocupar muitas posições na estrutura do judiciário. Importantes patriarcas garantiram a seus filhos, sobrinhos e afilhados o acesso aos cargos ambicionados. João Nunes dos
Reis, por exemplo, porteiro de auditório no início do século Xx, teve cinco filhos homens, dos quais quatro ocupavam posições na Secretaria do Tribunal de Justiça do Rio de Janeiro, sendo João Reis e Álvaro Reis, oficiais de justiça, Francisco Nunes dos Reis, técnico do judiciário e Inácio Pedro dos Reis, chefe da portaria.

$\mathrm{O}$ ingresso na carreira, à época do Império, era feito mediante nomeação dos juízes de direito. Eles podiam nomear e demitir livremente os oficiais de justiça (Buzaid, 1972). Conta-nos o oficial José Mello da Rocha Neto:

"Eles ficavam por ali, nas imediações do cartório, esperando por alguma coisa... Então, houve na época uma contratação de uma marca de patente de cerveja. $\mathrm{O}$ juiz do cartório onde meu avô fazia ponto, chamou meu avô e perguntou: 'ô Rocha, você quer ser oficial de justiça?' Ele foi e disse: 'quero.' Então, eu vou te dar um mandado de prisão pra você trazer três cidadãos aqui. Eram três alemães, donos de uma cervejaria. Eles tinham que prestar depoimento e não compareciam. Daí que o juiz expediu um mandato de prisão e o vovô sabia que o objetivo era aquele, deles prestarem o depoimento. Aí ele pegou uma carruagem e foi até o local onde eles trabalhavam e convidou, não prendeu não! Convidou os três a o acompanharem até a sede do juízo. Os três entraram na carruagem e foram com meu avô. Chegando lá, vovô falou pro juiz 'olha, as pessoas que o senhor convidou estão presentes'. Aí o juiz ouviu o depoimento dos três. Então você veja, pelo que o vovô falava, era um mandado de prisão, só que ele deu outra conotação, mas não deixou de cumprir o objetivo: o objetivo era que eles estivessem em juízo! Como meu avô cumpriu a obrigação, depois que os três foram embora, ele cobrou do juiz e esse no ato preencheu a nomeação do vovô na pretoria" (José Mello da Rocha Neto, Setembro de 2003).

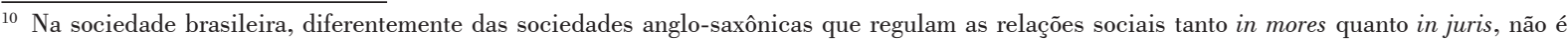
atribuído voluntariamente um estatuto oficial à identidade étnica.

${ }^{11}$ Paulo Verani escreveu, na década de 1980, um importante texto dirigido aos ciganos chamado Nós, no qual apontava a relevância de se assumir a identidade étnica. Tal proposição se inscreve no que Axel Honneth (2003) chama de luta por reconhecimento, necessária para que os indivíduos possam referir-se coletivamente e a si mesmos como sujeitos políticos. Nesse sentido, novas demandas dos ciganos brasileiros por direitos e reconhecimento culminaram com um Decreto Presidencial de 2006, instituindo o dia 24 de maio como o Dia Nacional do Cigano. A primeira discussão

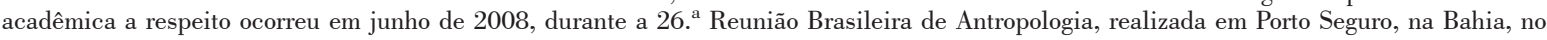
Simpósio Especial Os Ciganos e as Políticas de Reconhecimento: Desafios Contemporâneos, organizado por Marco Antonio da Silva Mello (MELLO \& VEIGA, 2008). Nessa ocasião, além das pesquisas apresentadas por Felipe Berocan Veiga, Alexandra Castro (CET-ISCTE) e Antonio Guerreiro (UNIRIO), o calon Zanata Ribeiro Dantas e Dom José Edson Santana Oliveira, Bispo de Eunápolis e responsável pela Pastoral dos Nômades no Brasil, também se manifestaram publicamente nessa direção.
} 
Eis uma história cujos elementos constituem uma referência quase paradigmática à forma de inserção dos ciganos no judiciário. Em princípio, enfatiza-se a posição espacialmente estratégica nas "imediações do cartório", para em seguida sua narrativa explicitar algo importante sobre uma condição fundamental para o êxito no exercício desta função que por si lida, eminentemente, com situações de constrangimento: a competência para negociar com as partes envolvidas numa contenda processual. Para finalizar, diante da prova de reconhecida habilidade na função, o sujeito era agraciado com sua nomeação.

Com o passar dos anos, para ingressar na carreira $^{12}$, era necessário fazer uma prova de habilitação, o que não diminuiu a importância do juiz no processo de contratação, pois sua indicação é condição sine qua non para fazer a prova e ser nomeado, caso aprovado. A indicação implicava, portanto, uma boa relação com o magistrado. Diante disso, os ciganos, então, construíram uma eficaz "rede de apadrinhamento", a qual permitia que eles fossem indicados para fazer a prova e depois, mediante aprovação, nomeados para a função pretendida. Os ciganos mantinham boas relações com os magistrados, agradavam-nos sendo subservientes e fazendo muitos favores ${ }^{13}$, conforme relata o tabelião Nadilvar Caetano Gomes:

"Faziam de tudo para agradar os juízes, manobravam carro, faziam às vezes de chofer... Os danados eram muito bajuladores. Era uma verdadeira oligarquia" (Nadilvar Caetano Gomes, Novembro de 2001).
O expressivo número de ciganos no juízo, sobretudo até a década de 1970, para Alípio Mendes e Galba Loureiro, oficiais de justiça aposentados, se explica pela forte solidariedade que imperava no grupo, o que possibilitava, cada vez mais, a incorporação de novos membros do clã na função, sobretudo diante da estreita relação mantida por eles com os magistrados.

"As esposas, quase sempre, serviam aos juízes e desembargadores em termos particularizados. Assim como, por exemplo, na lavagem de roupa, faziam comida, cantavam na casa deles. Havia, então, uma familiaridade entre eles que eles externavam poder, a autoridade e pagavam pelo benefício. Tem alguém pra ser nomeado... Entendeu? Isso durou, durou, durou... Aí, em 1950 e qualquer coisa, começou a ter os concursos" (Alípio Mendes e Galba Loureiro, Julho de 2002).

Porém, para o calon José Mello da Rocha Neto, o fator primordial para o emprego de tantos membros de sua família no judiciário resulta da prematura socialização na profissão. Isto é, o cigano, ainda muito jovem, acompanhava seu pai, tio ou avô sistematicamente ao trabalho. Por volta dos quatorze anos, o cigano era iniciado no ofício na condição de ajudante. Daí, na ocasião em que se encontrava com idade para ocupar o cargo, diante da experiência que ele já possuía, tornava-se um candidato preferencial aos olhos do juiz, o qual, por sua vez, vislumbrava no jovem a continuidade dos bons serviços prestados pelo pai.

\footnotetext{
${ }^{12}$ Com a Constituição Brasileira de 1988, é estabelecido o concurso público como forma de ingresso. Vale destacar, no entanto, que ainda hoje alguns oficiais podem ser nomeados ad hoc.

${ }^{13}$ É interessante notar que os ciganos assumem posturas diferenciadas segundo a interação. Diante dos juízes, não era oportuno e nem cabia se apresentarem como "gente temível e temida, figuras solenes", tal como a antiga descrição de Manoel Antonio de Almeida. Cultivavam, então, perante aos juízes, um estereótipo de docilidade e timidez, acentuando inclusive, de acordo com depoimentos, o quanto sua identidade étnica, recorrentemente associada a comportamentos reprováveis, era, portanto, passível de muito preconceito. A identidade desvantajosa nesse caso não era mascarada, mas explorada.
} 
Diagrama 2

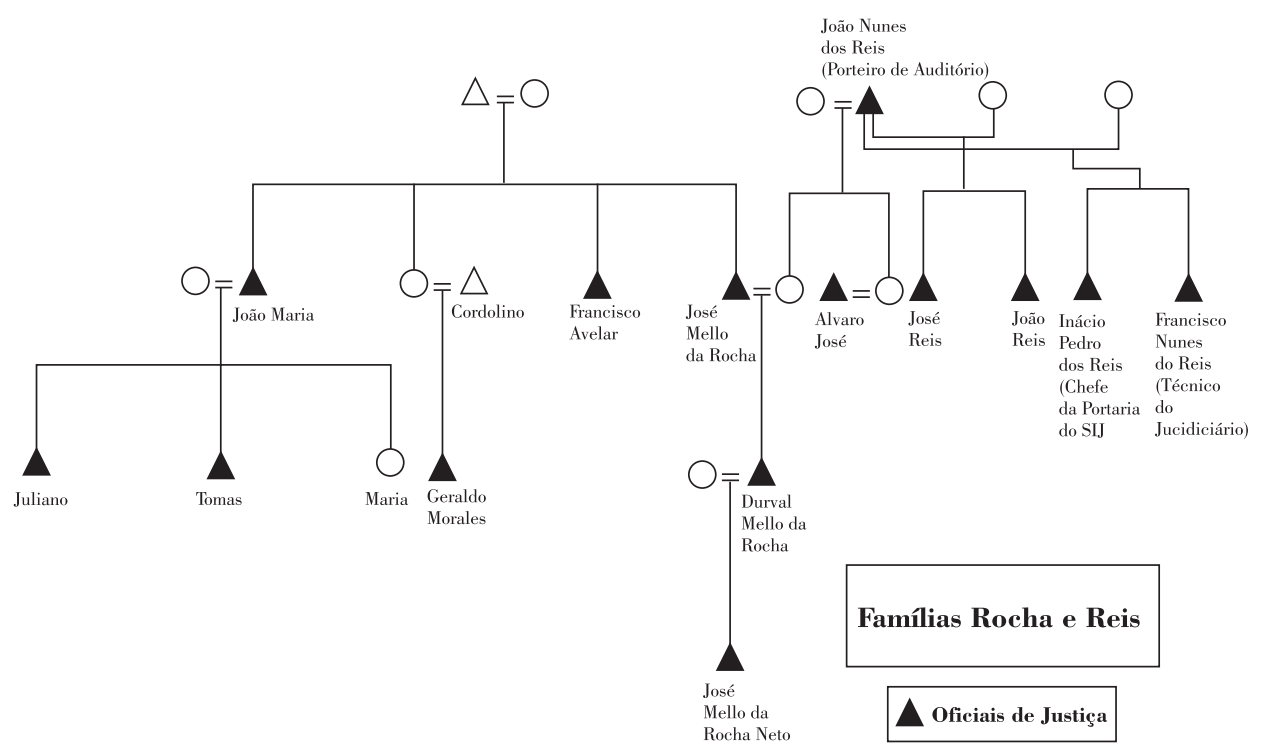

Genealogia das famílias Rocha e Reis e suas quatro gerações de funcionários da justiça.

\section{O processo e suas custas}

O magistrado não pode exercer sozinho as atividades necessárias ao julgamento das pretensões dos litigantes. Diante da diversidade de atos praticados até o desfecho da causa, o juiz deve ser auxiliado por diversas pessoas, que compõem o juízo. Entre essas pessoas, figura o oficial de justiça para praticar, especialmente, os atos que são feitos fora do lugar de trabalho do juiz. Por essa razão, entre os membros do judiciário, costuma-se dizer que "o oficial de justiça é os pés e os olhos do juiz", ou seja, o longa manus da autoridade judicial ${ }^{14}$.

Dessa forma, o seu exercício profissional implica um constante movimento por conta do seu relevante papel de mediador entre as partes envolvidas no processo e entre o juiz da vara, ao qual é subordinado, e o cartório, onde são emitidas as certidões referentes aos litígios. O desempenho desse papel permite a ele, portanto, uma grande mobilidade, além de assim ser um portador de "fé pública", ou seja, de ter o respaldo da lei para executar suas funções. Consideramos indispensável assinalar que ele também desfruta de uma relativa liberdade de decisão quanto à organização do seu trabalho; isto é, ele encaminha um considerável número de ordens judiciais de acordo com a sua própria disposição.

A constituição daquilo que chamamos de uma economia do judiciário é construída a partir, principalmente, dessa liberdade de organizar o seu trabalho; em outras palavras, do poder dos oficiais de justiça de apressar ou retardar o litígio, visto que são eles os responsáveis pela ordem de entrega dos documentos judiciais, sendo, assim, muito mais que simples portadores das decisões ordenadas pelo juiz. Ao trabalharem, em sua maioria, nas varas cíveis $^{15}$, conseguiam incluir nas custas, ou seja, nas despesas feitas em processo judicial, gorjetas recebidas dos autores das ações ${ }^{16}$. É oportuno salientar que as gorjetas, embora não inseridas nas despesas referentes às custas, são de fundamental importância para o bom andamento do processo. Ou melhor, a pessoa que propõe a ação, assim pedindo o exercício da função jurisdicional, oferece uma gratificação ao oficial de justiça para que ele apresse a citação ou a intimação da pessoa contra a qual a ação é proposta.

A gorjeta, contudo, não é tomada, pelos integrantes do judiciário, como algo ilegal, uma vez que sua existência cria condições mais favoráveis para o exercício profissional do oficial de justiça.

\footnotetext{
${ }^{14}$ Trata-se de uma clara evocação da fórmula de André João Antonil (1711), a mais conhecida quando se trata da caracterização do trabalho escravo no Brasil colonial: "Os escravos são as mãos e os pés do senhor de engenho, porque sem eles no Brasil não é possível fazer, conservar e aumentar fazenda, nem ter engenho corrente" (2007:97).

${ }^{15}$ Órgãos jurisdicionais que cuidam de toda a parte referente às relações jurídicas que envolvam bens móveis, imóveis, contratos, etc.

${ }^{16} \mathrm{O}$ que seria uma incongruência; afinal, trata-se a gorjeta de uma doação a alguém cujo serviço nos pareça meritório.
} 
Ela torna possível, por exemplo, que o funcionário do juízo utilize o serviço de um táxi, por exemplo, facilitando e agilizando sua locomoção até o réu. De acordo com o desembargador José Alves de Brito, em relação às gratificações, não há previsão específica na regulamentação vigente ${ }^{17}$.

Esse complemento, entretanto, não representa uma novidade do ponto de vista da história dos procedimentos administrativos da justiça. Em um documento da Mesa do Desembargo do Paço referente ao pedido de contratação de novos oficiais para a secretaria do Tribunal, feito ao Príncipe Regente em 27 de agosto de $1821^{18}$, observamos que, diante da necessidade de se pôr em dia o expediente e não permitindo o estado das rendas públicas que se tomassem medidas onerosas à Real Fazenda, foi ordenada a contratação de oficiais, os quais seriam pagos exclusivamente a partir dos emolumentos dos papéis por eles expedidos.

Durante um considerável período, "os oficiais de justiça não recebiam ordenado, mas tão só salários e emolumentos, fixados para os diferentes atos em que intervinham" (Souza Pinto, Primeiras Linhas Sobre o Processo Civil Brasileiro, vol I, pp. 225-233 apud Buzaid, 1972). A permissão para o recebimento de emolumentos, contudo, não era estendida a todos os funcionários do juízo. Os oficiais de registros, atualmente o que poderíamos chamar de escrivães, tinham um ordenado estabelecido e a eles eram interditadas as gratificações dos autores e, menos ainda, dos réus.

O recebimento de dinheiro da parte contra a qual a ação é proposta é terminantemente vetado. O oficial de justiça, como já apontamos, pode agilizar o processo ou retardá-lo; nessa última situação, alegando não encontrar o réu, ou seja, argumentando a impossibilidade de citar ou intimar a parte em questão. Em breves linhas, consideramos oportuno apresentar um caso que nos parece exemplar: certa ocasião, um advogado reclamou que um oficial estava retardando demasiadamente a entrega de um mandado no caso de um arresto de bens num estabelecimento comercial. A demora na citação estava possibilitando ao réu, por conseguinte, se desfazer da mercadoria que deveria ser apreendida. De acordo com o advogado, o comerciante prova- velmente planejava decretar falência e, com isso, quando o mandado fosse entregue, o autor já não teria mais nada a receber. A queixa do advogado foi investigada e, uma vez constatado que o oficial, com efeito, retardou a intimação, o mesmo foi encaminhado ao juiz. Nesse caso em particular, por causa da boa relação de sua família com o magistrado responsável, o oficial que protelou a intimação foi somente transferido para outra vara.

Embora a infração administrativa cometida pelo oficial não tenha sido punida conforme o código de organização do judiciário ${ }^{19}$, ela foi, segundo o senhor Nadilvar, extremamente severa, pois o oficial foi transferido para uma vara criminal:

"Mandar um oficial de justiça para uma vara criminal é pior do que mandá-lo para a cadeia! (...) Eles odiavam vara oficializada porque nelas não tem como regatear. Não tem gorjeta do autor! E o Estado, vai dar gorjeta? Tinha que viver só com o salário, se quisesse pegar um táxi, era com o dinheiro deles..." (Nadilvar Caetano Gomes, Novembro de 2001).

Nesse sentido, a possibilidade de estabelecer uma relação econômica com as partes envolvidas na contenda pode ser caracterizada como um elemento bastante vantajoso em uma profissão cuja remuneração, segundo os próprios oficiais, não era muito atrativa. No caso especial dos ciganos, podemos considerar que ela representava a manutenção de uma rede de práticas mercantis que, como observamos, permitiram a eles uma inserção privilegiada na economia e na sociedade brasileira.

O estabelecimento dessas relações sócioeconômicas, primeiro através da participação no comércio escravista e, depois, no negociar com as partes a gratificação pelos serviços exemplarmente prestados, garantiu ao grupo, além de uma operação de inversão no conjunto de valores estigmatizantes que lhe era atribuído na sociedade européia, a possibilidade de desfrutar de uma intensa mobilidade no tecido urbano. Mobilidade e liberdade essas que apontam para as representações cultivadas pelos ciganos acerca deles próprios ${ }^{20}$ e que correspondem à própria condição de instauração do mercado, seja ele o de escravos, seja ele o da regulação dos litígios.

\footnotetext{
${ }^{17}$ Ver o Ato Executivo n. 597/2003, publicado no Diário Oficial do Estado do Rio de Janeiro. Ano XXIX N. 119, Parte III.

${ }^{18}$ Mesa do Desembargo do Paço (1799-1834), Arquivo Nacional: Caixa 152, DOC 11.

${ }^{19}$ As infrações administrativas cometidas pelos serventuários, funcionários da justiça concursados, estão expostas nas Regras da Corregedoria Geral da Justiça.

${ }^{20}$ Em recente publicação, Marc Bordigoni retoma criticamente uma série de representações correntes no senso comum sobre o grupo, analisando e discutindo o quadro de esterétipos negativos e positivos em frases como "os ciganos são nômades", "os ciganos são ladrões", "os ciganos têm a música no sangue", etc. (Bordigoni, 2007).
} 


\section{Bibliografia}

ALMEIDA, M.A. (1978) Memórias de um Sargento de Milícias. Edição crítica de Cecília de Lara. Rio de Janeiro: LTC, [1854] $372 \mathrm{p}$.

ANTONIL, A. J. (2007) Cultura e Opulência do Brasil por suas Drogas e Minas. São Paulo: Ed.USP, [1711]. 464 p.

ARAÚJO, S.; GUERREIRO, A. (1999) O Samba Cigano: um estudo histórico-etnográfico das práticas de música e dança dos ciganos calom do Rio de Janeiro, Música Popular em América Latina: Actas del II Congreso Latinoamericano IASPM, Santiago, pp. 233-239.

BARTH, F. (1984) Problems in Conceptualizing Cultural Pluralism, with Illustrations from Somar, Oman. In: MAYBURYLEWYS, D. (Ed.) The Prospect for Plural Societies. Proceedings of The American Ethnological Society, pp. 77-87.

BORDIGONI, M. (2007) Les Gitans. Paris: Le Cavalier Bleu Éditions (Collection "Idées Reçues"), 125 p.

BUZAID, A. (1972) A Carreira do Oficial de Justiça. Parecer do Professor Dr. Alfredo Buzaid. Rio de Janeiro: Associação dos Oficiais de Justiça do Estado da Guanabara, 12 p. Opúsculo.

COLLECCẼO DA LEGISLAÇ̃̃O ANTIGA E MODERNA DO REINO DE PORTUGAL (1819), Legislação Antiga, Parte I. Collecção Chronologica de Várias Leis, provisões e Regimentos del Rey D. Sebastião para Servir de Appendix. Coimbra: Real Imprensa da Universidade de Coimbra.

DEBRET, J.-B. (1975) Viagem Pitoresca e Histórica ao Brasil. 6." ed. São Paulo: Martins; Brasília: INL, Tomo I, v. II [1834].

DONOVAN, B. M. (1992) Changing Perceptions of Social Deviance: Gypsies in Early Modern Portugal and Brazil, Journal of Social History, v. 26, n. L, pp. 33-53.

GOFFMAN, E. (1975) A Representação do Eu na Vida Cotidiana. Petrópolis: Vozes, 233 p.

HONNETH, A. (2003) Luta por Reconhecimento: a gramática moral dos conflitos sociais. São Paulo: Editora 34, 296 p.

LEGISLAÇÃO BRASILEIRA (1996), Código de Processo Civil. 26." ed. Org. Juarez de Oliveira. São Paulo: Saraiva.
MELLO, M. A. S.; SOUSA, M. A. (2006), Meirinhos aristocráticos, Revista de História da Biblioteca Nacional, ano 2, n. 14 Rio de Janeiro, pp. 29-32.

MELLO, M. A. S.; VEIGA, F. B. (2008) Os Ciganos e as Políticas de Reconhecimento: desafios contemporâneos. Associação Brasileira de Antropologia - ABA, disponível in: http://www. abant.org.br/noticias.php?type $=$ outranoticia\#329

MELLO, M. A. S.; VOGEL, A; SANTOS, C. N. F. et al (1981), Quando a Rua Vira Casa: A apropriação de espaços de uso coletivo em um centro de bairro. $2 .^{\mathrm{a}}$ ed. rev. e atualizada. Rio de Janeiro: IBAM; FINEP, 152 p.

MESA DO DESEMBARGO DO PAÇO (1799-1834), ARQUIVO NACIONAL: Caixa 152, DOC 11 e Caixa 154, DOC 97.

MORALES DE LOS RIOS FILHO, A. (2000) O Rio de Janeiro Imperial. 2." ed. Rio de Janeiro: Topbooks; UniverCidade Editora [1946]. 549 p.

MORAES FILHO, M. (1904) Factos e Memórias: A mendicidade do Rio de Janeiro. Ladrões de rua. Quadrilhas de ciganos. Memórias do Largo do Rocio. Memórias da Rua do Ouvidor Rio de Janeiro; Paris: H. Garnier Livreiro-Editor, 344 p.

RAMOS, A. (1947) Introdução à Antropologia Brasileira: As culturas européias e os contactos raciais e culturais. Vol. II. Rio de Janeiro: Livraria-Editora da Casa do Estudante do Brasil - CEB, 641 p.

SAINT-HILAIRE, A. M. (1976) Viagem à Província de São Paulo. Belo Horizonte: Itatiaia; São Paulo: Ed.USP [1851], 229 p.

SANTOS, L. G. (Padre Perereca). (1981) Memórias para Servir à História do Reino do Brasil. Belo Horizonte: Itatiaia; São Paulo: Ed. USP [1825], 336 p.

SCHWARTZ, S. B. (1979) Burocracia e Sociedade no Brasil Colonial: A Suprema Corte da Bahia e seus Juízes (1609-1751). São Paulo: Perspectiva, 354 p.

SOARES, C. E. L.; GOMES, F. (2001) Em busca de um "risonho futuro": Seduções, identidades e comunidades em fugas no Rio de Janeiro escravista (séc. XIX), Locus: Revista de História. v. 7, n. 2. Juiz de Fora, pp. 9-28.

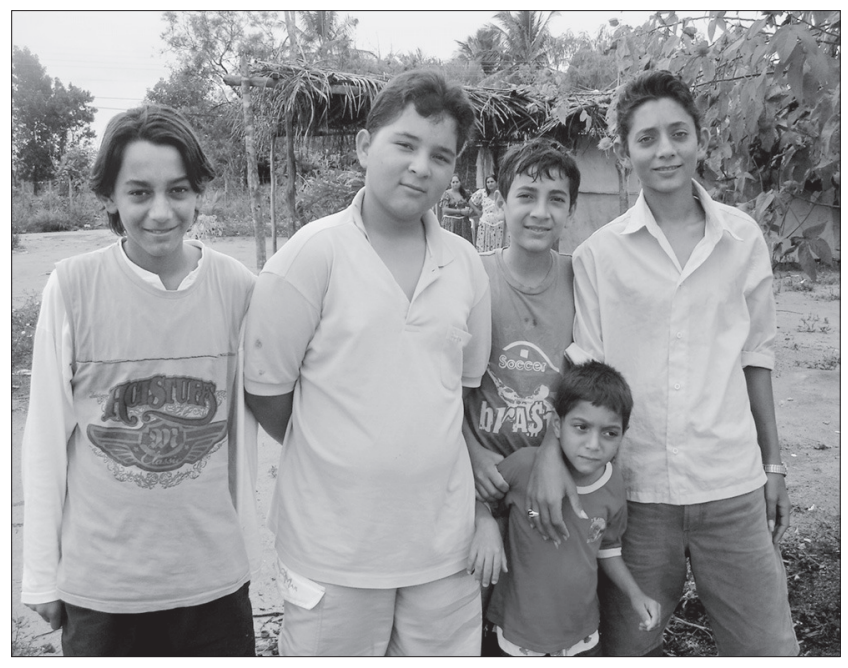

(a) Marco Mello 